\title{
A Community-Based Vulnerability Assessment of Terrestrial Flooding in the South Oropouche River Basin After Tropical Storm Bret
}

\author{
Don Charles ${ }^{1}$ \\ ${ }^{1}$ University of the West Indies, St. Augustine Campus, Trinidad and Tobago \\ Correspondence: Don Charles, Economics Consultant, Trinidad and Tobago.
}

Received: June 27, 2018

doi:10.5430/ijba.v9n4p166

Accepted: July 12, 2018

Online Published: July 19, 2018

URL: https://doi.org/10.5430/ijba.v9n4p166

\begin{abstract}
The year 2017 had a very active season for hurricanes and extreme weather conditions. Hurricanes Harvey, Irma, and Maria did damage to several Caribbean islands. Even Trinidad and Tobago (T\&T), a country which rarely experiences extreme weather conditions, was affected by Tropical Storm Bret. Tropical Storm Bret caused flooding in T\&T, especially in the low lying South Oropouche River Basin.

There is a dearth of research conducted in T\&T about the impact of extreme weather conditions and flooding on communities and families. Thus, this study sought to conduct a community base vulnerability assessment (CBVA) of the impact of the Tropical Storm Bret induced flooding upon the residents of the South Oropouche River Basin.

Primary data was collected via semi-structured interviews and questionnaires to conduct the CBVA. Furthermore, this study introduced a Modal Community Based Vulnerability Assessment Index (MCBVAI) to help determine which factors the residents South Oropouche River Basin are most vulnerable to.

This study found that the most vulnerable residents were vulnerable largely to their building of structures at locations unsuitable for housing. Moreover, the most vulnerable residents also built structures that were not resilient to flooding and was elevated less than 4 feet (ft) off the ground. The appropriate policy response for the Government of the Republic of Trinidad and Tobago (GORTT) would be to i) establish building codes, ii) develop a comprehensive spatial planning strategy which prohibits people from building structures in unsuitable areas, and iii) implement disaster risk reduction programmes which focus on improving pre-event disaster preparedness, improving the national and local response, and promoting educational awareness.
\end{abstract}

Keywords: community-based vulnerability assessment, flooding, Trinidad and Tobago

\section{Introduction}

Over the past decades, issues of climate-related disasters have become a major area of concern for several countries. Although both developed and developing countries may be affected by climate-related natural disasters, developing countries with significant resource and technical capacity constraints have been known to be more vulnerable. Ordinarily, 'vulnerability' is used to refer to one's susceptibility to harm (Turner et al. 2003). But in the context of climate-related stressors, vulnerability refers to the extent to which a system unable to cope with, negative effects of hazard or adverse event (Mccarthy et al. 2001).

In broad terms, vulnerability has two schools of thought. The natural hazard school of thought focuses on the risk of exposure of an ecosystem to a hazard, while the political economy school of thought accentuates the exposure of social unit to the hazard (Vincent 2004). The Intergovernmental Panel on Climate Change (IPCC) elucidates that climate-related vulnerability is the extent to which a system is susceptible to and unable to cope with adverse effects of climate change, inclusive of climate variability and extreme weather conditions (IPCC 2007). The IPCC also highlight that a comprehensive assessment and understanding of the vulnerability of an area is critical for developing adaptive measures and resilience building (IPCC 2001; IPCC 2007).

Small Island Developing States (SIDS) are highly vulnerable to climate change impacts, due to the combination of higher exposure, for example to sea-level rise and storm surge, as well as their limited capacity to adapt (Pelling and Uitto 2001; Kelman and Jennifer 2009; Shah et al. 2013). Caribbean islands are also vulnerable to climate change impacts (ECLAC 2011). The severe weather conditions which occurred in the year 2017 clearly demonstrated this (Note 1).

Trinidad and Tobago (T\&T), a SIDS located in the Caribbean, is also expected to be impacted by climate-related 
stressors. While several Caribbean islands (Note 2) experienced significant infrastructure damage from the 2017 season's major hurricanes-Harvey, Irma, and Maria, T\&T had to address floods, especially in the low terrain South Oropouche River Basin. T\&T was not spared from extreme weather conditions, as on June 20, 2017, the country was hit by the Tropical Storm Bret, which was accompanied by significant flooding in the South Oropouche River Basin.

In recent times the occurrence of severe weather conditions in the Caribbean region, and uncompromising flooding in low terrain South Oropouche River Basin in T\&T has heightened the need for disaster preparedness. Such disaster preparedness could be enhanced through the utilization of tools which serve to assess the extent of vulnerability of affected areas. In fact, Community-Based Vulnerability Assessment (CBVA) can be used for such vulnerability assessment.

The CBVA framework serves to identify the range of vulnerabilities experienced by residents within the community, existing adaptation deficits at the individual level, as well as adaptation deficits at the policy level. Such information can be useful for disaster preparedness, and climate change adaptation policy.

Several studies have conducted CBVA, which in turn have been used to inform disaster preparedness strategies in their respective jurisdictions (Villordon 2014; Antwi et al. 2015). However, such research is lacking in T\&T. A knowledge gap exists about the extent to which terrestrial flooding affects people in the South Oropouche River Basin in T\&T.

As a result, this study research objective is to undertake a Community-Based Vulnerability Assessment of terrestrial flooding in the South Oropouche River Basin after Tropical Storm Bret. The corresponding research questions are as follows:

1) who (what groups) was affected by the flooding?

2) how and why are they affected by the flooding?

3) what was their response to the flooding?

4) what was the government response to the flooding?

5) what policy response should be adopted in the future?

This study aspires to provide an empirical contribution to the Community-Based Vulnerability Assessment of terrestrial flooding literature, with this case study of the South Oropouche River Basin in T\&T.

This study is structured as follows. Section two will review flooding in Trinidad and in the South Oropouche River Basin. Section three will outline the Methodology for Community-Based Vulnerability Assessment. Section four provides the results. Section five presents a discussion. Section six concludes.

\section{Flooding in Trinidad}

The Republic of Trinidad \& Tobago is a twin-island sovereign state situated 11 kilometers $(\mathrm{km})$ off the coast of northeastern Venezuela. Collectively, the islands cover a land area of $5,130 \mathrm{~km}^{2}$ (Eitzinger et al. 2015) (Note 3). The country also experiences a tropical marine climate, with the rainy season occurring between June and December (CDERA 2003).

While several Caribbean islands lie in the hurricane belt, the location of T\&T in the extreme south of the Caribbean has protected it from the major hurricanes in the past. In fact, there is no documented incidence of Trinidad being hit by a major hurricane, while Tobago has only experienced two since 1963 . Notwithstanding, T\&T is subject to tropical storms and the associated heavy rainfall, often resulting in flooding (CDERA 2003).

A review of monthly precipitation data on T\&T from the World Bank (2018) over the 1991 to 2015 period suggests that rainfall in the country seems to be unchanged at roughly $250 \mathrm{~mm}$ every year over the period. Figure 1 provides a Hodrick-Prescott Filter, which extracted the trend and the cyclical component from out of the precipitation data. 
Hodrick-Prescott Filter (lambda=14400)

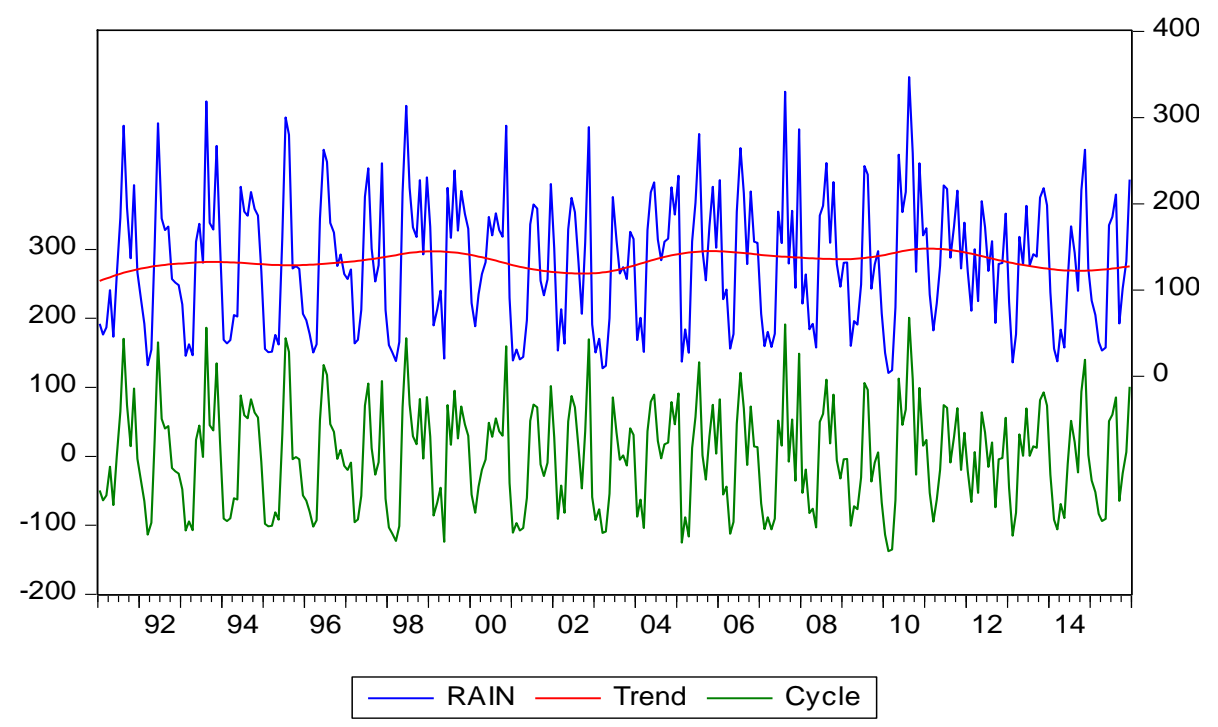

Figure 1. Hodrick-Prescott filter on monthly rainfall data in T\&T (1991-2015)

Although there seems to be no change in average rainfall in the country, flooding is a recurring problem in Trinidad and Tobago. In both islands, it causes substantial crop destruction, damage to property and household appliances, health problems, and severe inconvenience to whole communities on an annual basis. Perennial flash floods tend to occur along the foothills of the Northern Range, the Caparo River Basin, and the South Oropouche River Basins. In fact, flooding tends to occur along the floodplains of the Caroni, Caparo, North Oropouche and South Oropouche River Basins. Figure 2 provides an illustration of the watershed network in Trinidad.

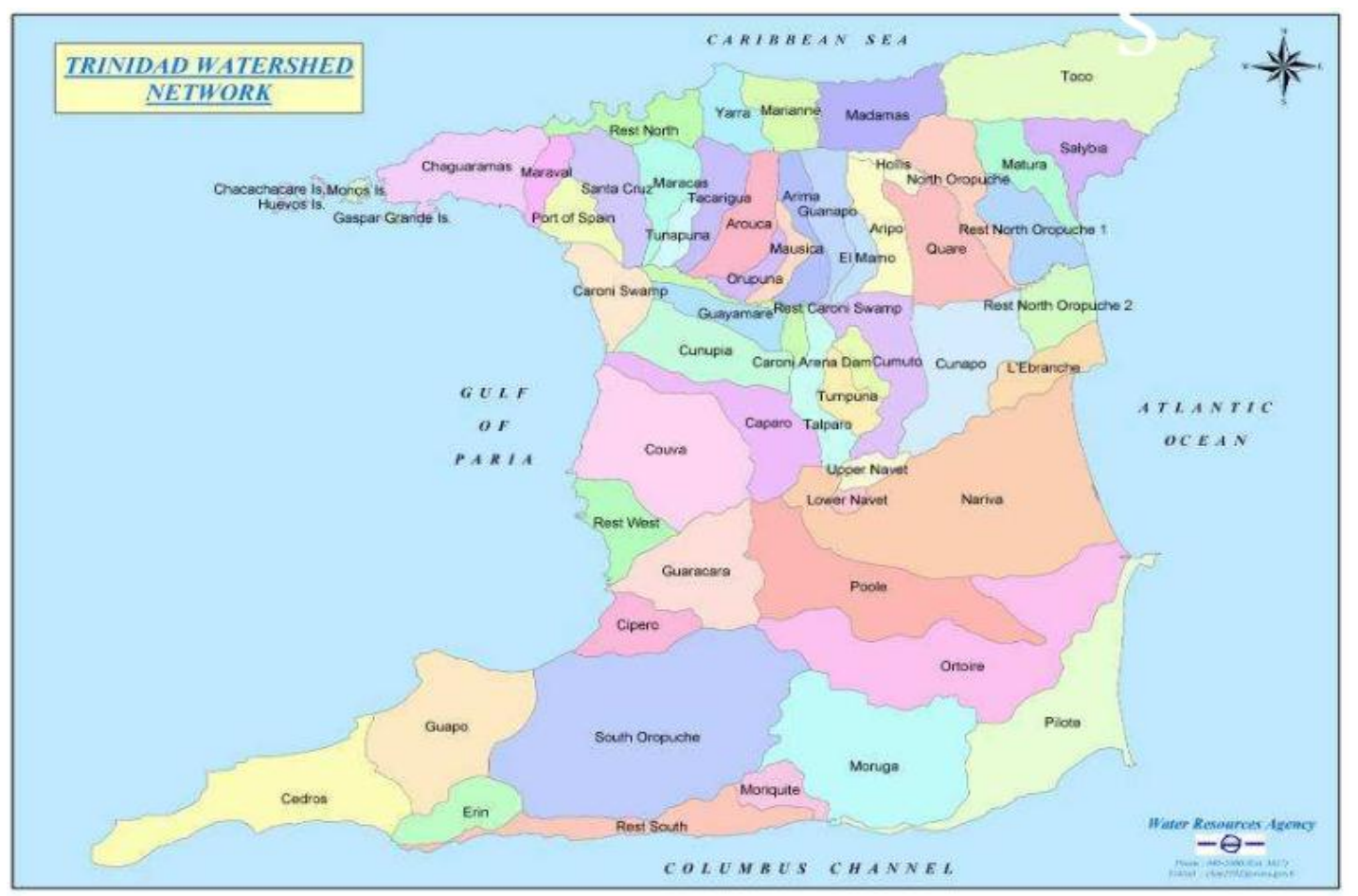

Figure 2. Trinidad watershed network

Source: McCormick (2017) 
Unsustainable land use practices (such as slash and burn agriculture, quarrying, illegal logging, and illegal settlements) contributes to soil becoming more exposed and therefore more susceptible to being washed away during periods of heavy rainfall and subsequent runoff (Few et al. 2004; Ramlal and Baban 2007). This results in heavy sedimentation in the river channels, reducing the size of the channels, consequently causing the flooding. Furthermore, the lack of vegetation cover from deforestation leads to much shorter lag times between precipitation and the water reaching the waterways, engendering the already restricted-capacity waterways to overflow (Ramlal and Baban 2007).

The South Oropouche River Basin is a very important basin for the drainage of surface-water in South Trinidad. From a hydrological point of view, the area has not been registered with exceptionally high rainfall records, nor inadequate drainage over its catchment area. Three groups of streams and micro-basins from the North, South-West, and South-East parts of the basin are used to collect runoff volumes in the entire catchment area. The South Oropouche River and the Godineau River are the main rivers used to drain the basin and are located at the basin's center. A number of man-made sluices are also used to help drain the basin. The sluice flow to the Western area of the basin, to discharge surface-water runoff. The two main sluices, the Trinidad Sluice and the St. John Sluice are used to help control the penetration of seawater inland during high tide (Heinzeller and Nebelsick 2005) (Note 4).

In contrast to the Caroni River Basin, the South Oropouche River Basin is not densely populated. In fact, the 2011 Population and Housing Census of T\&T indicated that the Penal/ Debe area's population density was 363 persons per $\mathrm{km}^{2}$, making it the $9^{\text {th }}$ most densely populated area in the country (Note 5). Siparia was even less densely populated, with a population density of 165 persons per $\mathrm{km}^{2}$ (CSO 2012). The combined population density of Penal, Debe, and Siparia is 237 persons per $\mathrm{km}^{2}$, which is relatively small to 1,416 persons per $\mathrm{km}^{2}$ population density of Chaguanas (Note 6).

With regards to transportation infrastructure, the San Fernando - Penal Highway is the most significant road network in the area. Over the 2010 to 2018 period, the Government of the Republic of Trinidad and Tobago (GORTT) commissioned work for an extension of the San Fernando - Penal Highway to Point Fortin. The Oropouche River Basin does not contain any of the industrial estates which are typically used for commerce, and employment generation in Trinidad (Note 7). The perennial flooding which occurs in the basin is likely to affect agricultural output and residents of the area. Hence, the flooding would impose some costs to the residents of the South Oropouche River Basin, therefore, there is a need for intervention to address the problem (Heinzeller and Nebelsick 2005, 1326).

\section{Methodology: Community-Based Vulnerability Assessment}

Vulnerability assessments are performed to determine the impact of a natural hazard upon people. Environmental vulnerability statistics (such as the environment vulnerability index, and the natural disaster risk vulnerability index) may not be an accurate reflection of vulnerability in various regions as vulnerability is not evenly distributed across sectors or communities (Smit and Wandel 2006). For this reason, Community-Based Vulnerability Assessment is a better framework, as it draws on the lived experience of stakeholders to capture how vulnerability is expressed for the multitude of affected actors.

The community-based approach differs from the conventional vulnerability assessments as it addresses both physical, and social vulnerability. Moreover, Community-Based Vulnerability Assessment social component recognizes that not every person or group of people have equal access to resources to cope with disasters (UNC Institute for the Environment, and MDC, Inc. 2009).

Community-Based Vulnerability Assessment is vulnerability assessments which incorporate the experiential knowledge of the people who have lived through disasters and who understand how such disasters make them vulnerable. This approach improves the effectiveness of the vulnerability assessment and ensures that the assessment is relevant to the stakeholders that are most at risk.

Community-Based Vulnerability Assessment is operationalized via case studies that document i) the nature of the hazard or threat; ii) the vulnerable groups of people; iii) critical facilities and communication systems; iv) environmental sensitivity; and v) mitigation and adaptation responses (Maharaj 2014).

The hazard identification and analysis involves the evaluation of the nature of the threat. It involves the review of how often the particular hazard occurs and the magnitude of damage imposed by the hazard.

The social vulnerability analysis involves the assessment of the impact of the hazard upon different groups of people. Different groups of people in any population have varying ability to adequately absorb, respond to and recover from the impacts of hazards and disasters. Traditionally, the groups of people with limited capacity tend to include: i) the 
elderly; ii) young children; iii) differently able people; iv) people with language barriers; people with health-related impairments; and v) the poor.

The critical facilities are the structures, institutions, industries, networks and systems that are essential to the security, health and safety of the society in the country of interest. An assessment of the critical facilities involves the assessment of emergency centers, communication networks, first responders, etc.

The purpose of the environmental sensitivity is to identify locations where there may be a potential secondary environmental impact from the natural hazard. For example, following the Great East Japan Earthquake of magnitude 9.0 at $2.46 \mathrm{pm}$ on Friday 11 March 2011, a 15-meter tsunami disabled the power supply and cooling of three Fukushima Daiichi reactors, causing a nuclear accident on the same day (WNA 2017). In the case of a flood, some of the areas which may be sensitive to secondary impacts include heavy industrial sites, and chemical production sites, and power plants.

Mitigation and adaptation responses refer to the relief systems used by the public authorities, and the adaption responses of affected individuals to advert and mitigate the impact of the hazard.

Thus, Community-Based Vulnerability Assessment involves the conducting of surveys to acquire primary data about the vulnerability of individual households. The survey is structured to encompass a range of issues, such as the identification of the groups of people which are vulnerable to the threat; the assessment of people's access to food, water, cooking fuel, and energy supplies; the appraisal of waste disposal practices; the evaluation of disaster experiences and response mechanisms; and the examination of people's susceptibility to health-related challenges (ADB 2011).

\subsection{Proposed Vulnerability Index}

To objectively determine which factors the residents South Oropouche River Basin are most vulnerable to, this study proposes the use of a vulnerability index. Note, the proposed index will not indicate the vulnerability of every person in an affected community to flooding. Rather, the index intends to reflect the modal value of which factors that affect the vulnerability of communities to flooding.

The factors which influence the value of the proposed Community Based Vulnerability Assessment Index include i) the individual impact; ii) food security; iii) water security; iv) health security; v) critical facilities; and vi) the public authorities' response. The data on the aforementioned factors are collected from the semi-structured interviews and questionnaire.

A scoring scale is used to determine the vulnerability of each factor. The scoring scale is ranked from 1 to 3 . A value of 1 indicates high vulnerability, a value of 2 indicates moderate vulnerability, and a value of 3 indicates low vulnerability. For instance, if the health security is scored 3, it means that in the affected community, the affected residents had a low vulnerability to health-related challenges as a consequent to the floods.

The researcher used the data acquired on the vulnerability factors to assign a score to each vulnerability factor. Afterward, the score from each vulnerability factor was summed to produce the Modal Community Based Vulnerability Assessment Index (MCBVAI). The term "modal" is used as the most frequent observation (the mode) was used to help determine the appropriate score for each factor.

Thus, the equation for the Modal Community Based Vulnerability Assessment Index is expressed

$$
M C B V A I=I I+F S+W S+H S+C F+P R
$$

Where $I I$ denotes the individual impact, $F S$ is food security, $W S$ is water security, $H S$ is health security, $C F$ is critical facilities, and $P R$ is the public authorities' response.

\subsection{Data Collection Framework}

Secondary data on the vulnerability of the residents of the South Oropouche River Basin to flooding is not readily available in T\&T. Therefore, primary data was collected. The data collection methodology for the CBVA was comprised of a focus group, a transect walk of the study area, and semi-structured interviews (using questionnaires) of residents in the study area. The entire data collection occurred over the September 2017 to November 2017 period.

A total of 8 persons were used in the focus group. To eliminate potential gender bias, the focus group was comprised of 4 men and 4 women. Since the main communities in the South Oropouche River Basin are Fyzabad, Siparia, Penal, and Debe, a man and a woman from each community were included in the focus group. The focus group was helpful as it supplied information about the flooding problem, without the common "knee-jerk" response used in a survey. In fact, the information from the focus group provided insight about which areas in the South Oropouche River Basin is 
prone to flooding, where to target people for the semi-structured interviews, and appropriate questions to ask in the questionnaire (Note 8). The information about where to target people for the sampling was used to minimize coverage error (Note 9).

The transect walk was also undertaken along with 2 persons from the focus group, both of which were from the Fyzabad area. Both guides claimed to have lived in Fyzabad for over 40 years, and were well familiar with all 4 communities under study. The transect walk was used to highlight which areas in the communities were prone to flooding, and which waterways in the communities are likely to overflow their banks first.

To determine an appropriate sample size for the semi-structured interviews, the researcher reviewed the number of households for the Penal, Debe, and Siparia areas in the 2011 National Census (Note 10). The census data reported that in 2011, the number of households in Penal/ Debe was 27407, while the number of households in Siparia was 26280. Collectively, there were 53,687 households in Penal, Debe, and Siparia. A visual inspection of the Trinidad Hazard and Response Map from the National Emergency Management Agency (NEMA) revealed that approximately $20 \%$ of the land area in the South Oropouche River Basin is prone to flooding. Assuming the households are uniformly distributed, there would be approximately 10,737.4 households vulnerable to flooding. Since only 1 researcher was used for the data collection, a sample size of 1,076 households (approximately $10 \%$ of the vulnerable population) was targeted.

A stratified random sampling framework was used to select respondents for the interviews. Since there were 4 communities under study, 269 semi-structured interviews were undertaken in each community. The researcher acknowledges that there are differences in the population density between the communities, but choose not to have a disproportionate strata size as the 4 communities are in relatively close proximity to each other. In each community, each respondent was selected by chance, and each member of the population has an equal chance of being included in the sample.

Each semi-structured interview was preceded by a questionnaire which the researcher asked the respondent to fill out. To eliminate non-response error to each question in the questionnaire, the researcher also asked the respondents alternate questions in the semi-structured interview. In fact, as the questions in the semi-structured interview were openly structured, it allowed the respondents to talk at length about the topic of interest. It is noteworthy that the researcher asked each respondent the same questions in the questionnaire in an alternative manner as a test-retest method (Note 11) to ensure the reliability(Note 12) of the results.

To ensure the validity (Note 13) of the results, the results of this study are compared to the results of similar studies. To guarantee anonymity, respondents were not required to provide their personal information such as their names, residential addresses or telephone number.

\section{Results}

According to the data collected from the random sampling, 586 respondents $(54.46 \%)$ were female, and 490 respondents $(45.53 \%)$ were male. Responses were obtained from both male and female residents of each community. The amount of respondents from each community is clearly seen in Table 1.

Table 1. No of respondents per community

\begin{tabular}{lllllllll}
\hline Community & \multicolumn{2}{l}{ Fyzabad } & Siparia & Penal & \multicolumn{3}{c}{ Debe } \\
\hline Gender & Male & Female & Male & Female & Male & Female & Male & Female \\
No. of respondents & 170 & 99 & 85 & 184 & 84 & 185 & 151 & 118 \\
\hline
\end{tabular}

All respondents that were interviewed and administered the questionnaire reported more than 1 person living in their household. Table 2 displays a frequency distribution table of the number of people per household reported by the respondents. It can be clearly seen that the modal measure was 4 people per household. 
Table 2. Frequency distribution of the No. of people per household

\begin{tabular}{ccc}
\hline No of people per household & Frequency & Percentage \\
\hline 1 person & 8 & $0.7 \%$ \\
2 persons & 53 & $5 \%$ \\
3 people & 129 & $11.98 \%$ \\
4 people & 731 & $67.99 \%$ \\
5 people & 108 & $10 \%$ \\
6 people & 43 & $3.99 \%$ \\
7 people & 4 & $0.3 \%$ \\
\hline
\end{tabular}

With regards to the age of the respondents, $71.7 \%$ of the respondents (772 people) were in the age range of 20-30; $22.7 \%$ of the respondents ( 245 people) were in the age range of $31-40$; and $5.48 \%$ of the respondents (59 people) were in the age range of over 40 . People under the age of 20 were not interviewed in the study (Note14).

322 respondents $(30 \%)$ reported that they lived in single-parent households. In each case, the respondents indicated that a female-headed the single parent household. Additionally, a total of 893 respondents reported that there was at least one child under the age of 10 living in their household. Out of the single parent families, 207 respondents $(19.23 \%)$ reported having at least one child under the age of 10 living in their household. 164 respondents (15.3\%) reported having at least one person over the age of 60 living in their household.

Table 3 displays a frequency distribution Table of the number of years the respondents lived in a community in the study area. $55.3 \%$ of the respondents reported having lived in a community in the study area for over 20 years. In fact, $93.1 \%$ of the respondents reported having lived in a community in the study area for at least 5 years.

Table 3. Frequency distribution of the number of years residing in the community

\begin{tabular}{lcc}
\hline No of years residing in your community & Frequency & Percentage \\
\hline Under 5 years & 74 & $6.9 \%$ \\
5-10 years & 161 & $15.0 \%$ \\
$11-20$ years & 245 & $22.8 \%$ \\
over 20 years & 596 & $55.4 \%$ \\
\hline
\end{tabular}

All 1,076 respondents (100\%) reported being affected by flooding in their community. However, the explanation of how they were affected varied. All respondents indicated that they were affected by the flood waters entering main roads, thereby restricting their ease of traveling through their community. 964 respondents $(89.6 \%)$ stated that flood waters typically enter their yard whenever a major flood occurs. However, only 268 respondents $(24.9 \%)$ stated that flood waters entered their home as a consequence to the flooding induced by the Tropical Storm Bret. These 268 respondents also indicated that the flooding associated with the Tropical Storm Bret was not the first time that flood waters entered their homes.

The residents reported during the flooding that followed Tropical Storm Bret, the flood waters were as deep as 3-4 $\mathrm{ft}$ in some areas. In the instances where it entered people's homes, it caused damage furniture (tables, chairs, couch sets, beds), and electrical appliances (fridges, deep freezers, washing machines), and cars. The residents also reported that after the flood there was significant sedimentation left indoors. 5 respondents reported that there were cracks to their house after the incident.

Residents also reported that the strong winds from Tropical Strom Bret blew off the roof of several houses in Siparia, Penal, and Debe, although none of the respondents claimed to have experienced the same. Residents also reported that there were downed trees and power-lines in the aftermath of Bret. Additionally, the Debe Hindu SDMS, the Fyzabad Anglican School, the Fyzabad Secondary School, and the Rousillac Hindu School were closed after the storm due to the need to undertake cleaning and maintenance.

The respondents claimed that the following areas are highly inclined to experience flooding.

- In Fyzabad
- St John's Trace;
○ South Delhi Road; and
○ Forest Reserve Road. 
- In Siparia
- SS Erin Road; and
- Rahamut Trace.

- In Penal

- Clarke Road;

- San Francique Road;

- Penal Rock Road; and

○ Rochard Road.

- In Debe
- Picton Estate Road;
- Lalbeharry Trace; and
- Ramai Trace.

Figure 3 provides a map from T\&T illustrating the flood-prone areas in the South Oropouche River Basin. The areas shaded green and flood-prone areas.

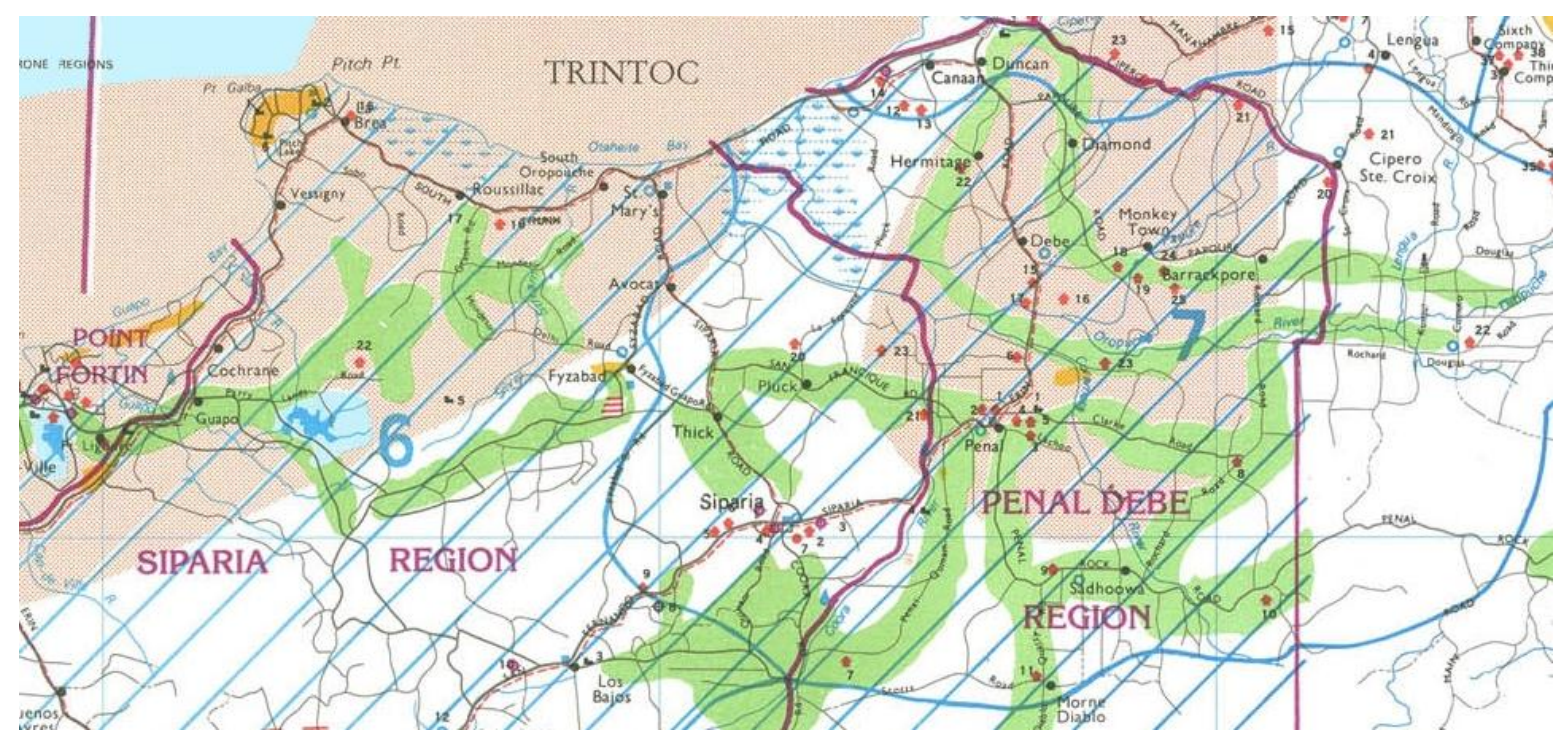

Figure 3. Flood-Prone areas in the South Oropouche River Basin

Source: NEMA (2004)

Only 112 of the respondents (10.4\%) reported that flood water never enters their yard. Despite the high likelihood of flooding in specific areas of the South Oropouche River Basin, only 174 respondents (16.17\%) reported that their house stood on pillars in excess of 6 feet.

The 268 respondents that claimed flood waters entered their home during the Bret induced flooding stated that they used multiple methods to address the flood water. All such respondents expressed that their method to address flooding involved putting light household appliances (e.g. TVs, radios, computers, phones, kitchen appliances, etc.) on elevations inside their homes to prevent the direct contact with water. 127 respondents reported that they try to keep water out by keeping entry and exit doors to their home shut. However, they expressed that this method was not very effective in the Bret induced flooding. 6 respondents claimed to use self-made sandbags to around doors to prevent flood water from entering their homes. They claim that their sandbag method is typically effective, but it was not absolutely effective during the Bret induced flooding. Furthermore, they claimed that they were trapped indoors during the Bret induced flooding. 
4 respondents from Penal claimed to live in ply-wood houses. They expressed that during the Bret induced flood, the flood water, saturated the ply-wood walls and wooden floor, rendering the house uninhabitable. They were forced to temporarily seek refuge with family on higher terrain. Upon returning to their home, they observed that there was damage to their house, as well as household appliances.

15 respondents stated that the flood waters from Bret lasted for approximately 2 weeks before going down. They also stated that they could not relocate to prime properties which are not prone to flooding as such properties would cost in excess of TT $\$ 200,000$ (US\$31,000).

Out of the 268 respondents that stated flood waters entered their home during the Bret induced flooding, only 3 claimed to have housing insurance.

It is noteworthy that out of the 268 respondents that were affected by the Bret induced flooding, 262 (24.3\% of the sample) of them claimed to come from households with at least 4 people. 210 respondents $(19.51 \%$ of the sample) indicated that their households had at least one child under the age of 10.96 respondents ( $8.92 \%$ of the sample) indicated that they lived in single-parent families. Additionally, 49 respondents (4.55\% of the sample) stated that they had at least 1 person over the age of 60 living in their household.

Although the South Oropouche River Basin is relatively sparsely populated, only 72 people claimed to grow their own food. In fact, all 59 people in the "over 40" age range stipulated that they grow at least some of their food. Although, only 22 of such respondents considered themselves as farmers, and involved in both crop and livestock farming.

12 of the respondents claiming to be farmers were from Penal, while 10 were from Debe. During the interview, the farmers stated that their cultivated crops included tomatoes, pineapples, bananas, celery, chive, and patchoi. All of the farmers stated that they had some poultry, however, only 1 respondent claimed to be involved in the rearing of goats, piglets, and poultry.

All 22 respondents which claimed to be farmers reported that their total loss from the Bret induced flood was in excess of TT $\$ 100,000$. The owners of livestock stated that during floods, they let their animals loose in their fields to "fend for themselves."

No respondent reported experiencing any food shortage after a flood. They expressed that they would typically have sufficient food stored inside their homes, which would not get in direct contact with the flood water. In fact, out of the 268 respondents that claimed to experienced water entering their homes, 82 of them claimed to resorting to buying food after Bret.

All 1,076 respondents reported using cooking gas (propane) for cooking. No traditional method, such as the use of firewood, was used.

With regards to water security, all respondents stated that they received a relatively regular supply of water from the Water and Sewage Authority (WASA), the monopoly water distribution company in T\&T. However, all the respondents noted, that every month, there are disruptions to the water supply, where there may be no water for a few hours to a few days.

All respondents reported that they store water. 867 respondents (80.5\%) stated that they use water tanks, drums, and buckets as storage mediums. Only 209 respondent expressed that they rely solely on drums and buckets as storage mediums. 968 respondents reported that their water storage capacity was at least 600 gallons.

All the respondents reported that their wastewater from washing dishes and clothes eventually end up in some wastewater canal. However, 591 respondents $(54.9 \%)$ claimed that their wastewater from the toilet ends up in a septic tank. 474 respondents (44\%) were unsure of how their wastewater is disposed, while only 11 respondents were sure that their wastewater from the toilet ends up at a wastewater treatment plant.

947 respondents stated that their garbage was directly collected by a garbage truck. 129 respondents claimed that they dumped their garbage at a location where it would be collected by a garbage truck.

No respondent reported accruing any illness as a consequence of the Bret induced flooding.

All respondents agreed that the main routes of transportation in Fyzabad, Penal, Debe, and Siparia became difficult to commute across during the Bret induced flooding. In fact, the respondents also agreed that the main routes of transportation become relatively inaccessible (except to trucks, SUVs, vans, and other high vehicles) during large floods. 
The respondents expressed that the damage that arises from the flood varies on a case by case basis. They elaborated that debris from trees, chunks of earth, as well as human garbage, is often deposited on the roads, or in people's yards after the flood. While all the respondents agreed that the public authorities eventually remove the debris, they disagreed about the duration of time it took to complete the clean-up work from the Bret induced flooding and other major floods. 272 respondents stated that the clean-up from the Bret induced flooding took 2-3 weeks, 314 respondents stated that it took 1 month, while 490 respondents stated that it took in excess of 1 month.

The respondents stated that there are multiple schools in Fyzabad, Penal, Debe, and Siparia. A review of google maps in the aforementioned areas revealed

- 7 schools in Fyzabad;

- 19 schools in Penal/ Debe; and

- 10 schools in Siparia.

The respondents stated that flood water does enter the schools, but the extent of damage varies on a case by case basis. After Bret, the Rousillac Hindu School, which is in close proximity to Fyzabad, remained closed as the access roads to the school was flooded.

The respondents indicated that there is no major hospital in the South Oropouche River Basin. The San Fernando General Hospital services as the major hospital for the South Trinidad community. However, there are 3 public health centres in the South Oropouche River Basin. They include:

- $\quad$ the Siparia District Health Facility;

- the Fyzabad Health Centre; and

- the Penal Health Centre.

The respondents indicated that there are 4 police stations in South Oropouche River Basin. They include:

- the Santa Flora Police Station;

- the Siparia Police Station;

- the Siparia Municipal Police Station; and

- the Penal Police Station.

\subsection{Disaster Response of the Public Agencies}

With regards to the response from the government, prior to the storm, the Trinidad and Tobago Meteorological Office (Met Office) issued a series of updates. The update released at 6:00 pm on June 19, 2017, indicated that the Potential Tropical Cyclone \#2 developed into Tropical Storm Bret, and was expected to hit the country within 6 to 12 hours (OPPM 2017).

In response to advice from the Office of Disaster and Preparedness Management (ODPM) (Note 15), the Ministry of Education announced that all schools in the country were to be closed. The ODPM issued a list of shelters throughout Trinidad, while the Tobago Emergency Management Centre (TEMA) issued a list of emergency shelters for Tobago (Loop 2017b).

The ODPM also advised that all households should prepare a disaster kit, which would include: non-perishable food for each person in the household for at least 72 hours; sufficient water so that each person can consume 1 gallon a day for over 72 hours; a first aid kit; batteries and electric lights; radios; and miscellaneous items such as extra blankets, clothing, shoes and money (Loop 2017a).

After the passing of the tropical storm, the ODPM reported that the following Regional Corporations were most impacted: Penal/ Debe, Mayaro/ Rio Claro, Tunapuna Piarco, San Juan/ Laventille, Diego Martin, and the Arima Borough (San Pedro Sun 2017). Subsequently, all Disaster Management Units (DMU) of the 14 municipal corporations were scheduled to commence clean-up operations from 6:00 am on June 21, 2017 (the day after the Tropical Storm Bret hit the country). However, 22 respondents reported that the clean-up operation in some parts of Penal, and Debe commenced as long as 2 weeks after Bret as it took time for the flood waters to subside.

The secondary and primary schools in Fyzabad, Penal, Debe, and Siparia were all listed as shelters by the ODPM. However, 22 respondents reported that the schools were "paper shelters" as the government agencies did not equip the shelters with supplies which would be necessary if large numbers of people had to seek refuge in the shelters. 
The GORTT also used its ministries to provide direct support to people affected by the Bret induced flooding. For instance:

- The Ministry of Social Development and Family Services established a disaster relief operations centre, to fast-track the process for the issuing of grants for the families affected by Tropical Storm Bret.

- The Ministry of Housing and Urban Development provided the Emergency Shelter Relief Grant. This grant is given to members of the public, applicants, to conduct emergency repairs to housing units.

- The National Commission for Self Help makes available a grant facility called the emergency repair and reconstruction grant to mitigate against circumstances associated with natural disasters such as Tropical Storm Bret.

- The Ministry of Works and Transport continued its programme of desilting and cleaning of watercourses (Hansard 2017).

It is noteworthy that only 198 of the 1,076 respondents claimed to have received grants from a government agency. They reported that the total monies they acquired from the grants amounted to TT $\$ 10,000$. They also reported that they received the monies within 2-3 weeks from the date Tropical Storm Bret hit T\&T (June 20, 2017).

\subsection{Results of the Modal Community Based Vulnerability Assessment Index}

The results of the Modal Community Based Vulnerability Assessment Index are displayed in Table 4.

Table 4. Results of the MCBVAI

\begin{tabular}{lcccc}
\hline & Fyzabad & Penal & Debe & Siparia \\
\hline individual impact & 1 & 1 & 1 & 1 \\
food security & 3 & 2 & 2 & 3 \\
water security & 3 & 3 & 3 & 3 \\
health security & 3 & 3 & 3 & 3 \\
critical facilities & 3 & 3 & 3 & 3 \\
public authorities' response & 3 & 2 & 2 & 3 \\
MCBVAI & 16 & 14 & 14 & 16 \\
\hline
\end{tabular}

Recall, in the proposed Modal Community Based Vulnerability Assessment Index, a value of 1 indicates high vulnerability, a value of 2 indicates moderate vulnerability, and a value of 3 indicates low vulnerability.

In all 4 communities, the individual impact was scored at 1 (high vulnerability). This did not mean that everyone in the target community had a high vulnerability to flooding. The score of 1 was assigned to reflect that flood waters entered the homes of 268 respondents, the majority of which claimed to have no housing insurance. Furthermore, as the flood waters lasted as long as 2 weeks at some locations, the affected persons were relatively vulnerable to the flood. The interviews with the respondents revealed that such persons were most affected by the flood due to their residing on low terrain areas, not building their houses on pillars, and not building structures that are resistant to flooding.

The food security score was varied between 3-2 as respondents expressed that they able to purchase for cook food after the flood. Respondents were also able to source food from friends and family. The food security score was lower for Penal and Debe as 9 respondents from Penal, and 9 respondents from Debe claimed to suffer agricultural losses in excess of $\$ 100,000$, but only 2 respondents from Fyzabad and 3 respondents from Siparia claimed to suffer agricultural losses in excess of $\$ 100,000$.

Water security, and health security were all scored as 3 (low vulnerability) as the respondents did not reveal any water scarcity of health-related challenges as a consequence of the Bret induced flooding. Critical facilities were scored at 3 as all the communities under study had schools which could be used as shelters, health centres, and police stations.

The public authorities' response was allocated a score of 3 as the Met Office and the ODPM issued public warnings about the Tropical Storm Bret. The municipal corporations engaged in clean up works from June 21, 2017. The government also provided financial grants to affected families. However, the public authorities' response was allocated a score of 2 in Penal and Debe as 22 respondents (from Penal and Debe) criticized the public authorities' response. The respondents expressed that they felt that the public authorities could have done more, such as dredging 
of the drains when altered about the Tropical Storm, providing adequate supplies to the proposed shelters, and dispatching soldiers from all military bases to provide relief to affected residents.

\subsection{Comparison of the Results to Other Studies}

As previously mentioned, there is a dearth of Community-Based Vulnerability Assessment studies for T\&T. Subsequently, the only comparable studies are international ones. The topography, climate, and economic conditions will vary between $T \& T$, and other regions. Therefore, the absolute results of this study will differ from other studies. However, methodologies can be compared.

Antwi et al. (2015) used a probability proportional to size (PPS) method to sample four communities in Ghana: Chietanga, Baleufili, Bamkpama, and Zowayeli. The sample size of each community was selected in proportion to the total number of households in each community. The selected sample size of 104 respondents was approximately $40 \%$ of the total population. In each community, two focus groups were conducted to complement the household survey. Transect walks were also undertaken to visualize the topography of the target areas.

Antwi et al. (2015) computed a vulnerability index to measure the vulnerability of residents in the target communities to flooding. Their index for measuring household and community level vulnerability was determined by four popular vulnerability indicators: engineering, socio-economic, ecological and political. A vulnerability indicator score of $0-33.33 \%$ was considered highly vulnerable and assigned a value of (3); 33.34-66.66\% moderately vulnerable and assigned a value of (2) and $66.67-100 \%$ was least vulnerable hence a value of (1).

Antwi et al. (2015) found that more than $71 \%$ of their respondents were male-headed households. The average household size of the communities fell between 6 and 10 people. The population was relatively young as the majority of respondents were between 21 and 60 years.

The Total Community Vulnerability (TCV) computed provided a cumulative vulnerability score for all the vulnerability indicator factors. Chietanga, Bamkpama, and Zowayeli were found to be the most vulnerable to ecological factors (river size, landscape with high biodiversity, landscape with agroforestry, sacred groves and reserved area, woodlot, and crop diversification). The research methodology used in this study was comparable to that of Antwi et al. (2015).

Villordon (2014) performed a Community-Based Vulnerability Assessment of the people of Dumaguete City, the Philippines, to fluvial flooding. Villordon (ibid) sampled 357 households from 12 communities and 30 respondents from local government units and non-governmental organizations (NGOs). The researcher also computed a community-based flood vulnerability index (FVI) to measure the vulnerability of affected residents to urban flooding. The index was comprised of 5 vulnerability components and 6 indicators. The results of the study revealed that Barangay Tabuctubig was the most vulnerable community, and its most vulnerable indicators were hydro-climatic, social, economic, socio-behavioral, and the politico-administrative.

\section{Discussion and Recommended Adaptive Policy}

Flooding in the South Oropouche River Basin after Tropical Storm Bret did not affect every resident in the affected communities evenly. The flood water has a tendency to cover roads, and increase the difficulty of commuting across communities. Flood water also enters the yard of residents of low lying areas in Fyzabad, Penal, Debe, and Siparia. However, floodwater only enters the homes of the people that reside on the low terrain and their houses are elevated less than $4 \mathrm{ft}$ above the ground. In a sample of 1,076 respondents, the affected sample was only 268 respondents (24.9\% of the sample).

In the instances where flood water entered people homes, they experienced damages to furniture, damages to household appliances, sedimentation inside of their house, and in some cases minor cracks to their house. Some people also experienced some damages to their car.

Women, and children under the age of 10 are vulnerable groups of flooding in the South Oropouche River Basin. Such vulnerability arises from women, and children under the age of 10 being a significant demographic in the population.

The residents' ability to adapt seems to be constrained. The residents expressed difficulty in relocating to less flood-prone areas as prime land which is not prone to flooding is often in excess of TT $\$ 200,000$ in T\&T. Additionally, once a house has already been built, it can't be automatically raised on pillars without undergoing significant foundation and upgrade works. Subsequently, residents have adapted to the flooding problem by placing light household appliances on elevations inside of their homes to prevent the direct contact with water, keeping entry 
doors to their homes shut, and using sandbags around doors to prevent the entry of flood water. Unfortunately, the closed-door method results in several residents being marooned within their home whenever a major flood occurs.

While questions regarding income were not directly asked, as the researcher was strongly advised against doing so in the focus group, income does not seem to factor contributing to vulnerability. This assertion is made as residents affected by the flooding do not seem to face any food or basic supplies shortage in the aftermath of a flood. In fact, after Bret, 82 families claimed to be able to buy food. There seems to be no outbreak of any waterborne illness after a flood. Furthermore, the farmers that suffer the greatest loss from the flood seem to be very resilient as they absorb their losses, reinvest in crops and livestock, and continue to function without a major financial burden. Thus, it seems that the residents are unable to stop the flooding, but being affected by major floods does not impose major economic hardships on the affected people.

Part of the resilience of the affected community is due to strong government support. For instance, the farmers mentioned that the price of seeds/ grain, as well as chickens (young poultry) is very cheap in T\&T, allowing the farmers to easily reinvest after suffering losses. The government also provided grants to residents, and farmers in communities affected by the Bret induced flooding.

Civil society groups, such as the Friends of Fyzabad, the Penal/Debe Foundation, and the Honda Legends prepared and delivered hot meals to stranded residents. The civil society groups also collected donations, which were later distributed to the residents affected by the flood. Some of the supplies distributed by the civil society groups included water, tarpaulins, mattresses, and cleaning products such as bleach, disinfectant, soap, brooms, and mops.

Although the interviewed residents of Penal and Debe expressed dissatisfaction with the government's response (Note 16), the GORTT through its agencies attempted to mitigate the effect of the Bret induced flooding on affected persons. For instance, the Met Office issues a series of updates about the tropical storm. The ODPM issued a series of public advisories about shelters, and preparatory material for people to store to help them overcome possible threats posed by Tropical Storm Bret. The government also had a number of first responder agencies (Note 17) to provide emergency assistance to people affected by Tropical Storm Bret. Additionally, after the passing of the Tropical Storm Bret, the GORTT provided financial grants to affected families.

\subsection{Adaptation Recommendations}

The respondents that claimed that flood water entered their homes through the plywood walls and wooden floor revealed a flaw in their building structure. It was clear that such respondents' homes were not built to be resilient to floods. This is a problem which could have been addressed by the implementation of building codes.

Currently, there is no system of building codes in T\&T. There is a system for the obtaining of permission to build on properties. The Town and Country Planning Act mandates that individuals must first obtain permission from the Town and Country Planning Division (TCPD) before the erection of new buildings and structures, or the renovation of existing buildings and structures (Laws of Trinidad and Tobago 1990). The people seeking building approval must submit the flowing to the Town and Country Planning Division: i) an application form; ii) a cadastral sheet (with the plot number) of the proposed building site; iii) a deed of the landowner; and iv) drawings for the structure (floor plans, foundation plans, elevation plans, location plans, and electrical drawings). After the application form is submitted, the Town and Country Planning Division dispatches a Development Control Inspector to visit the site to collect information related to the application. Afterward, an evaluation report is prepared and considered along with the application. After a two-month review process, applicants are notified if they have been approved and granted a Grant of Approval or denied via a Refusal of Outline Planning Permission.

Even though there is a system to grant permission for building, that does not ensure that any building or structure would be built to specific standards.

The Trinidad and Tobago Bureau of Standards (TTBS) has a Small Building Guide. The Guide outlines some basic criteria that should be followed when building small structures. However, the guide is not comprehensive enough to mandate building standards for the multitude of structures that can be built over different terrains in T\&T.

After flooding in Trinidad in 2011, the Cabinet of T\&T established a steering committee, the National Building Code Committee, to create a building code for the country (Douglas 2011; Lyder 2011). In 2015, the National Building Code Committee advocated for adapting of the International Code Council (ICC)'s International Building Code (IBC) in T\&T. The GORTT also signed an agreement with the ICC to adopt the IBC. However, as recent as 2018, neither the IBC nor a National Building Code has been established in T\&T. 
The effective implementation of building codes could mitigate the impact of floods upon affected residents in the South Oropouche River Basin. However, T\&T has a problem where several people build structures without seeking any Town and Country Planning Division approval. Additionally, people practice illegal squatting, even in the South Oropouche River Basin (Sletto 2002; Laing and Lewis 2017; Mycoo 2018). Therefore, a building codes system can only be effectively implemented if the public authorities undertake site visits to all structures under construction in the country and ensure compliance.

Another recommendation to address the flooding challenge is the adoption of land use planning and zoning in T\&T. In 1984, the GORTT approved the National Physical Development Plan (NPDP). Believing that the NPDP was outdated, in 2013, the GORTT prepared the National Spatial Development Strategy (NSDS) for Trinidad and Tobago. The NSDS aspired to be better than its predecessor as it mentioned that it incorporates economic, social and environmental matters in its spatial planning process.

While the NSDS recognizes that people reside in different geographic locations in the country, it does not create any zoning framework that prohibits people from building structures at locations which are known to be prone to flooding. Many low lying areas in the South Oropouche River Basin are unfit for occupancy. In fact, some people have built their homes at locations which can be considered as swamps or marshland (Note 18). A comprehensive spatial planning strategy should prohibit people from building structures in such unsuitable areas. Moreover, the public authorities should actively prohibit people from squatting on such unsuitable land. Unfortunately, the GORTT is relatively tardy in addressing illegal squatting. Thus, there is room for institutional strengthening at the Commissioner of State Lands (Note 19) level, to address illegal squatting.

Another policy recommendation is the GORTT to implement disaster risk reduction programmes which focus on improving pre-event disaster preparedness, improving the national and local response, promoting educational awareness. Such programmes, if properly implemented, should i) keep rivers, canals, and other waterways dredged and clear; ii) reforest and increase vegetation at hillsides to slow down surface water runoff; and iii) prevent problems like the non-provision of disaster relief supplies to emergency shelters, and the under dispatching of all first responders.

Moreover, there is scope for greater involvement of the civil society to help mitigate the effect of flooding upon affected communities. As previously mentioned, civil society groups provided support to residents in the South Oropouche River Basin. There is room for the GORTT to help build the capacity of civil society groups so that they can play an enhanced role in providing relief to residents affected by floods.

\section{Conclusion}

Based upon the Community-Based Vulnerability Assessment performed, the most vulnerable groups in the South Oropouche River Basin are the people living on low terrain and their houses are elevated less than $4 \mathrm{ft}$ off the ground. Women, and children under the age of 10 are vulnerable groups of flooding in the South Oropouche River Basin.

The proposed Modal Community Based Vulnerability Assessment Index revealed that the individual impact was the most significant factor affecting the vulnerability of residents in the South Oropouche River Basin. Such individual impact was a reflection of people's vulnerability due to their residing on low terrain that is prone to flooding, with relatively flat houses, that were not built to be resilient to flooding.

The most vulnerable residents tend to experience damages to furniture, damages to household appliances, sedimentation inside of their house, and in some cases minor cracks to their house, as a result of the Bret induced flooding.

The affected residents responded to the flood by closing entry doors to their home, and using sandbags. But such methods were not very effective in the Bret induced flooding. Residents ability to relocate to less flood-prone areas seemed to be constrained as the cost of such land would be in excess of TT\$200,000 (US\$31,000).

The GORTT response included public warnings through its Met Office, and the ODPM. It also dispatched first responders, and ordered the commencing of clean-up work from the day after the Tropical Storm Bret passed. Public financial grants were also made available to affected families. However, respondents expressed dissatisfaction with the government effort.

Since it was the people's location, and the standard to which they built their homes were the fundamental reasons why the most vulnerable were affected by Tropical Storm Bret induced flooding, then the appropriate policy response would be for the government to implement building codes, and a comprehensive spatial planning strategy should prohibit people from building structures in such unsuitable areas. 
In order to effectively adapt, the GORTT should implement disaster risk reduction programmes which focus on improving pre-event disaster preparedness, improving the national and local response, and promoting educational awareness.

\section{References}

ADB (Asian Development Bank). (2011). Community-Based Climate Vulnerability Assessment and Adaptation Planning. Retrieved December 11, 2017, from http://hdl.handle.net/11540/942

Antwi, E.K., John, B.D., Alex, B.O., Seyram, K.L., Ruby, M., Yaw, A.B., \& Priscilla, T.A. (2015). Community Vulnerability Assessment Index for Flood Prone Savannah Agro-Ecological Zone: A Case Study of Wa West District, Ghana. Weather and Climate Extremes, 10, 56-69. https://doi.org/10.1016/j.wace.2015.10.008

CDERA (Caribbean Disaster Emergency Response Agency). (2003). Status of Hazard Maps Vulnerability Assessments and Digital Maps: Trinidad and Tobago Country Report. Retrieved November 15, 2017, from http://dipecholac.net/docs/files/551-hazards-maps-vulnerability-assessment-trinidad-and-tobago.pdf

CSO (Central Statistical Office). (2012). Trinidad and Tobago 2011 Population and Housing Census Demographic $\begin{array}{lllll}\text { Report. } & \text { October } & 15, & 2017, & \text { from }\end{array}$

https://www.guardian.co.tt/sites/default/files/story/2011_DemographicReport.pdf

Douglas, Sean. (2011). Trinidad Newsday. Moonilal: New Building Code Soon. Retrieved December 30, 2017, from http://archives.newsday.co.tt/2011/11/27/moonilal-new-building-code-soon/

ECLAC (Economic Commission for Latin America and the Caribbean). (2011). Study on the Vulnerability and Resilience of Caribbean Small Island Developing States (SIDS). Retrieved October 14, 2017, from https://www.cepal.org/publicaciones/xml/4/45364/LCARL.354.pdf

Eitzinger, A., Aidan, F., Kevon, R., Stephania, C., Irene van, L., \& Michael, T. (2015). Trinidad \& Tobago: Assessing the Impact of Climate Change on Cocoa and Tomato. International Centre for Tropical Agriculture, 27, 1-6.

Few, R., Mike, A., Franziska, M., \& Sari, K. (2004). Floods, Health and Climate Change: A Strategic Review. Tyndall Centre Working Paper, 63, 1-139.

Hansard. (2017). Unrevised House of Representatives Debate. Retrieved June 22, 2018 from http://www.ttparliament.org/hansards/hh20170623.pdf

Heinzeller, T., \& James, H.N. (2005). Floods from Defence to Management. London, United Kingdom: Taylor and Francis Group.

IPCC (Intergovernmental Panel on Climate Change). (2001). Climate Change 2001 Summary for Policymakers: A Contribution of Working Group I, II and III to the Third Assessment Report of the Intergovernmental Panel on Climate Change. Cambridge, United Kingdom: Cambridge University Press.

IPCC (Intergovernmental Panel on Climate Change). (2007). Climate Change 2007: Impacts, Adaptation and Vulnerability. IPCC Fourth Assessment Report. Retrieved November 7, 2017, from https://www.ipcc.ch/pdf/assessment-report/ar4/wg2/ar4_wg2_full_report.pdf

Kelman, I., \& Jennifer, J.W. (2009). Climate Change and Small Island Developing States: A Critical Review. Ecological and Environmental Anthropology, 5(1), 1-16.

Laing, C., \& Acolla, L. (2017). Exploring Clustering as a Destination Development Strategy for Rural Communities: The Case of La Brea, Trinidad. Journal of Destination Marketing \& Management, 6(3), 184-195. https://doi.org/10.1016/j.jdmm.2016.03.006

Laws of Trinidad and Tobago. (1990). Town and Country Planning Act 29 of 1960. Retrieved December 30, 2017, from http://rgd.legalaffairs.gov.tt/laws2/alphabetical_list/lawspdfs/35.01.pdf

Loop. (2017a). List of Emergency Shelters in T\&T. Retrieved June 22, 2018, from http://www.looptt.com/content/list-emergency-shelters-tt

Loop. (2017b). Met Office Confirms Formation of Tropical Storm Bret. Retrieved June 22, 2018, from http://www.looptt.com/content/met-office-confirms-formation-tropical-storm-bret

Lyder, O. (2011). Moonilal: Report Soon On National Building Code. Sunday Express-Trinidad Express Newspapers November

24. Retrieved

December

30 ,

2017 ,

from 
https://www.trinidadexpress.com/news/local/moonilal-report-soon-on-national-building-code/article_e907bacefe95-58a2-8eaf-a0d263dc2b45.html

Mccarthy, J., Osvaldo, F., Canziani, N., Leary, A., \& Kasey, S.W. (2001). IPCC-Intergovernmental Panel on Climate Change. Climate Change. Impacts, Adaptation and Vulnerability. A Contribution of Working Group II to the Third Assessment Report of the Intergovernmental Panel on Climate Change (IPCC). Cambridge: Cambridge University Press.

McCormick, S. (2017). Water Resources Assessment of Trinidad and Tobago. Retrieved October 15, 2017, from http://docplayer.net/39099144-Water-resources-assessment-of-trinidad-and-tobago.html

Moench, M., \& Ajaya, D. (2004). Adaptive Capacity and Livelihood Resilience: Adaptive Strategies for Responding to Floods and Droughts in South Asia. Institute for Social and Environmental Transition.

Mycoo, M. (2018). Urban Sustainability in Caribbean Small Island Developing States: A Conceptual Framework for Urban Planning Using a Case Study of Trinidad. International Development Planning Review, 40(2), 143-174. https://doi.org/10.3828/idpr.2018.8

NEMA (National Emergency Management Agency). (2004). Trinidad Hazard and Response Map. Retrieved November 19, 2017, from http://ontheworldmap.com/trinidad-and-tobago/topographic-map-of-trinidad.jpg

ODPM (Office of Disaster and Preparedness Management). (2017). PUBLIC ADVISORY \# 3-Tropical Storm Bret-Monday 19th June, 2017. Retrieved October 22, 2017, from http://www.odpm.gov.tt/node/946

Pelling, M., \& Juha, I.U. (2001). Small Island Developing States: Natural Disaster Vulnerability and Global Change. Global Environmental Change Part B: Environmental Hazards, 3(2), 49-62. https://doi.org/10.1016/S1464-2867(01)00018-3

Ramlal, B., \& Serwan, M.J.B. (2007). Developing a GIS Based Integrated Approach to Flood Management in Trinidad, West Indies. Journal of Environmental Management, 88, 1131-1140. https://doi.org/10.1016/j.jenvman.2007.06.010

San, P.S. (2017). Tropical Storm Bret-Situation Report \# 1. Retrieved November 3, 2017 from https://www.sanpedrosun.com/weather/2017/06/20/tropical-storm-bert-situation-report/

Satapathy, S., Ilona, P., Dirk, R., Somya, B., Sanjay, T., \& Sreeja, N. (2014). A Framework for Climate Change Vulnerability Assessments. Deutsche Gesellschaft für Internationale Zusammenarbeit (GIZ) GmbH, India. Retrieved

from https://www.weadapt.org/sites/weadapt.org/files/legacy-new/knowledge-base/files/1522/5476022698f9agiz201 4-1733en-framework-climate-change.pdf

Shah, K.U., Hari, B.D., Craig, J., \& April, B. (2013). Understanding Livelihood Vulnerability to Climate Change: Applying the Livelihood Vulnerability Index in Trinidad and Tobago. Geoforum, 47, 125-137. https://doi.org/10.1016/j.geoforum.2013.04.004

Sletto, B. (2002). Producing Space (S), Representing Landscapes: Maps and Resource Conflicts in Trinidad. Cultural Geographies, 9(4), 389-420. https://doi.org/10.1191/1474474002eu256oa

Smit, B., \& Johanna, W. (2006). Adaptation, Adaptive Capacity and Vulnerability. Global Environmental Change, 16(3), 282-292. https://doi.org/10.1016/j.gloenvcha.2006.03.008

Suresh, K., Sanjeev, V.T., \& Geetha, S. (2011). Design, Data Analysis and Sampling Techniques for Clinical Research. Annals of Indian Academy of Neurology, 14(4), 287-290. https://doi.org/10.4103/0972-2327.91951

Turner, B.L., Roger, E.K., Pamela, A.M., James, J.M., Robert, W.C., Lindsey, C., \& Noelle, E. (2003). A Framework for Vulnerability Analysis in Sustainability Science. Proceedings of the National Academy of Sciences, 100(14), 8074-8079. https://doi.org/10.1073/pnas.1231335100

UNC Institute for the Environment, and MDC, Inc. (2009). Community Based Vulnerability Assessment: A Guide to Engaging Communities in Understanding Social and Physical Vulnerability to Disasters. Retrieved October 15 , 2017 , from https://www.mdcinc.org/wp-content/uploads/2017/11/Community-Based-Vulnerability-Assessment.pdf

Villordon, M.B.B. (2014). Community-Based Flood Vulnerability Index for Urban Flooding: Understanding Social Vulnerabilities and Risks. Doctoral thesis. Nice Sophia Antipolis University, Nice, France. 
Vincent, Katharine. (2004). Creating an Index of Social Vulnerability to Climate Change for Africa. Tyndall Center for Climate Change Research. Working Paper, 56(41), 1-50.

WNA (World Nuclear Association). (2017). Fukushima Accident. Retrieved December 12, 2017, from http://www.world-nuclear.org/information-library/safety-and-security/safety-of-plants/fukushima-accident.aspx

World Bank. (2018). Average Precipitation in depth (mm per year) in Trinidad and Tobago. Retrieved June 14, 2018, from https://data.worldbank.org/indicator/AG.LND.PRCP.MM

\section{Notes}

Note 1. The season had 17 storms, 10 hurricanes, and 6 major hurricanes. The season had the highest number of hurricanes since 2005 (Klotzbach and Bell 2017). Three of the season's major hurricanes-Harvey, Irma, and Maria did the majority of the damage.

Note 2. In 2017, the Caribbean region experienced a very active hurricane season, resulting in significant damage to Barbuda, Cuba, Dominica, Puerto Rico, the British Virgin Islands, and the US Virgin Islands.

Note 3. Trinidad is $4,828 \mathrm{~km}^{2}$ and Tobago is $302 \mathrm{~km}^{2}$.

Note 4. The man-made sluices contain gates, which are used to regulate water flow.

Note 5. The South Oropouche River Basin is comprised of the following communities: Fyzabad, Siparia, Penal, and Debe. In 2000 the population density for the Penal/ Debe area was 340 per km2. Therefore, the population density for the Penal/ Debe area increased over time.

Note 6. Chaguanas is a community in the Caroni River Basin.

Note 7. Currently, there are industrial estates in Point Lisas, Point-a-Pierre, and La Brea in Trinidad.

Note 8. In fact, during the focus group discussion, the researcher was advised by the participants of the focus group to refrain from asking income related questions in the questionnaire as the respondent residents may feel insecure.

Note 9. Coverage error occurs when the list from which a sample is drawn does not include all essential elements of the population that the researcher desires to study.

Note 10. There was no reported household data for Fyzabad in the 2011 National Census.

Note 11. The test-retest method is where the same test or question is administered to the same respondents twice to see if the results/ responses are the same.

Note 12. Reliability refers to the extent to which the research method is a consistent and dependable indicator of an investigation. In other words, a reliable method is one that consistently produces the same result regardless of how many times the method is applied (Suresh et al. 2011).

Note 13. Validity is the degree to which the research methodology accurately measures what it intended to measure (Suresh et al. 2011). A research methodology that is not reliable cannot be valid, but, a methodology can be reliable and still not be valid. Note, validity cannot be proved but it can be supported.

Note 14. The interviews were undertaken during the hours of 9 am and $2 \mathrm{pm}$. During such hours, people under the age of 20 were in school. The researcher did not go to any school to interview any resident of the study area.

Note 15. The ODPM is the government agency that is responsible for the coordination of disaster response in T\&T.

Note 16. One respondent from Penal indicated that there is an army base not far from Woodland, yet the base did not dispatch anyone to provide assistance.

Note 17. The first responder agencies in T\&T include the Regional Corporations, the Trinidad and Tobago Police Service, the Trinidad and Tobago Defence Force, and the Trinidad and Tobago Fire Service.

Note 18. Many areas in Fyzabad, Penal, Debe, and Siparia are low terrain. During the dry season, there is a relative absence of water at these locations, so they seem to be hospitable. Some people may opt to squat and build houses at these locations during the dry season. During the rainy season, or after a few days of rain, these locations are flooded with water.

Note 19. The Commissioner of State Lands is the legal landlord for all government-owned lands in T\&T. Only the Commissioner of State Lands has the legal authority to remove squatters off state lands in T\&T. 


\section{Appendix}

\section{Household Vulnerability Survey Form}

\section{Individual Characteristics}

1. Fill out the table below

\begin{tabular}{l|ll}
\hline \begin{tabular}{l} 
Which Community do $\begin{array}{l}\text { Gender (Male/ Female) } \\
\text { you live in? }\end{array}$ \\
\hline
\end{tabular} & $\begin{array}{l}\text { Age (20-30, 31-40, over } \\
40)\end{array}$ & $\begin{array}{l}\text { Number of people living } \\
\text { in your household }\end{array}$ \\
\hline
\end{tabular}

2. Are you living in a single parent household?

Yes $\square \quad$ No

If yes, is it female-headed?

Yes $\square \quad$ No $\square$

3. Are there children under the age of 10 living in your household?

Yes $\square \quad$ No $\square$

4. Are there elderly (over the age of 60) living in your household?

Yes $\square \quad$ No $\square$

5. How many years have you lived in your community?
Under 5 years
5-10 years $\square$
10-20 years
over 20 years

\section{Questions about Building/House}

6. Are you directly affected by flooding in your community?

Yes $\square \quad$ No $\square$

If yes, explain how

7. Does floodwater enter your home when flooding occurs?

Yes $\square \quad$ No $\square$

8. Which area in your community most prone to flooding?

9. Is your house raised above ground?

Yes $\square \quad$ No

10. Approximately how many meters above the ground is it raised?

11. What actions have you taken by to reduce the impact of flooding?

12. Is your house (building) insured?

Yes $\square \quad$ No $\square$ 


\section{Questions about Food Security}

13. Do you grow some of your own food?

Yes $\square \quad$ No $\square$

14. Do you experience a loss of crops/ livestock during floods? (tick appropriate area)

Loss to crops $\square \quad$ loss to livestock $\square \quad$ no losses

15. What is your estimated crop/ livestock loss?

Under $\$ 50,000 \square \quad \$ 50,00-\$ 100,000 \square \quad \$ 100,000 \square$

16. Have you ever experienced a food shortage or shortage of certain types of food after a flood?

Yes $\square \quad$ No $\square$

If yes, please elaborate

17. What fuel do you use for cooking?

\begin{tabular}{ll}
\hline Main Cooking Fuel & Percentage Use \\
\hline Firewood & \\
\hline Gas (propane) & \\
\hline Electric & \\
\hline Other & \\
\hline
\end{tabular}

\section{Questions about Water Supply}

18. Do you receive piped water?

Yes $\square \quad$ No $\square$

19. How often do you receive water? hours a day days for the week

20. Do you store water?

Yes $\square \quad$ No $\square$

21. What do you use to store water? (tick all that are appropriate)
Water tanks
Drums
Buckets

22. What is your total water storage capacity?
400 gallons
600 gallons
800 gallons
1000 gallons

23. Do you collect rainwater?

Yes $\square \quad$ No $\square$

24. What is your main source of drinking water?

\begin{tabular}{ll}
\hline Source & Percentage Use \\
\hline Piped water & \\
\hline Standpipe water & \\
\hline Bottled water & \\
\hline Rainwater & \\
\hline Spring water & \\
\hline
\end{tabular}

\section{Questions About Waste and Health Security}

25 . What happens to your wastewater?

Wastewater canal

If other, please specify
Septic tank $\square$

Wastewater treatment plant
Other $\square$ 
26. How do you dispose of your rubbish?

Garbage truck disposal $\square \quad$ burning $\square \quad$ direct disposal at dump $\square \quad$ Other

If other, please specify

27. Did you, or your family become ill as a direct consequence of the flood?

Yes $\square \quad$ No $\square$

28. If yes, what is the typical illness?

\section{Questions About Roads and Ease of Transportation}

29. When flood occurs, does it make the main routes of transportation in your community inaccessible?

Yes $\square \quad$ No $\square$

30. Do flood waters typically cause damage to the main routes of transportation in your community?

Yes $\square \quad$ No $\square$

If yes, please explain

31. Does the regional corporation respond promptly to undertake repairs and clean-up work after floods?

Yes $\square \quad$ No $\square$

32. How long does it take the regional corporation to complete repairs and clean-up work after floods?

1 week $\square \quad 2-3$ weeks $\square \quad 1$ month $\square \quad$ in excess of 1 month

\section{Questions about Infrastructure}

33. Are there any schools in your community?

Yes $\square \quad$ No $\square$

34. Are they affected by flooding?

Yes $\square \quad$ No $\square$

35. Are they any hospitals in your community?

Yes $\square \quad$ No $\square$

36. Are there any police stations in your community?

Yes $\square \quad$ No $\square$

37. What actions have the public authorities taken by to reduce the impact of flooding?

38. Have you received any government grant after the Bret induced flooding?

Yes $\square \quad$ No $\square$

If yes, please elaborate some more 